\title{
ANALISA KAPASITANSI SPESIFIK ELEKTRODA KARBON SUPERKAPASITOR dari KAYU KARET terhadap LAJU SCAN BERDASARKAN VARIASI AKTIVASI HNO
}

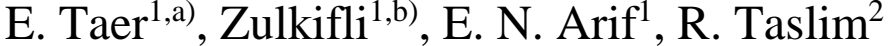 \\ ${ }^{1}$ Jurusan fisika, Universitas riau, Simpang baru, Pekanbaru, 28293 \\ ${ }^{2}$ Jurusan Teknik Industri, Universitas Islam Negeri Sultan Syarif Kasim, Pekanbaru, 28293 \\ Email: a)erman_taer@yahoo.com, b)izul_jundi@yahoo.co.id
}

\begin{abstract}
Abstrak
Variasi kapasitansi spesifik elektroda karbon superkapasitor dari kayu karet terhadap laju scan telah berhasil dianalisa. Pembuatan elektroda karbon meliputi proses pemotongan, pengeringan, karbonisasi, aktivasi, pemolesan dan penetralan. Aktivasi dilakukan secara bertingkat meliputi aktivasi fisika dan kimia. Aktivasi fisika dilakukan menggunakan gas $\mathrm{CO} 2$ pada suhu $850{ }^{\circ} \mathrm{C}$ selama 2 jam. Sedangkan aktivasi kimia dilakukan dua tahap yaitu dengan $3 \mathrm{M} \mathrm{KOH}$ kemudian diteruskan dengan aktivasi HNO3 menggunakan variasi konsentrasi sebesar 5\%, 15\% dan 25\%. Pengukuran sel superkapasitor dilakukan dengan metode siklis voltammetri pada laju scan $1-100 \mathrm{mV} / \mathrm{s}$ dalam larutan elektrolit $1 \mathrm{M}$ H2SO4.Hasil penelitian menunjukkan bahwa nilai kapasitansi spesifik mengalami penurunan secara eksponensial seiring dengan penambahan laju scan. Laju scan $1 \mathrm{mV} / \mathrm{s}$ menghasilkan kapasitansi spesifik tertinggi dan terendah sebesar $81,82 \mathrm{~F}$ g-1dan $10,44 \mathrm{~F}$ g-1, sedangkan pada laju scan $100 \mathrm{mV} / \mathrm{s}$ menghasilkan kapasitansi spesifik tertinggi dan terendah sebesar 19,67 F g-1 dan 4,66 F g-1, masingmasing untuk variasi HNO3 sebesar 25\% dan 5\%. Hasil pengujian SEM memperlihatkan elektroda karbon memiliki struktur pori yang seragam dan pengujian ED-X menunjukkan persentase unsur karbon tertinggi sebesar $92,53 \%$ terdapat pada sampel dengan variasi HNO3 $25 \%$.
\end{abstract}

Kata-kata kunci: Superkapasitor, Kapasitansi Spesifik, Laju Scan

\begin{abstract}
Specific capacitance variation of carbon electrode supercapacitor from rubber wood against scan rate have been successfully analyzed. Fabrication of carbon electrode includes cutting, drying carbonization, activation, polishing and neutralization. Activation was carried out in multi-step process covering the physical and chemical activation. Physical activation was performed by using $\mathrm{CO} 2$ gas at a temperature of $850{ }^{\circ} \mathrm{C}$ for 2 hour, while the chemical activation process was done by combination of $3 \mathrm{M} \mathrm{KOH}$ and HNO3 using a variation of concentrations as high as 5\%, $15 \%$ and $25 \%$. Supercapacitor cell measurements was performed using a cyclic voltammetry method at a scan rate of $1-100 \mathrm{mV} / \mathrm{s}$ in electrolyte solution of $1 \mathrm{M} \mathrm{H} 2 \mathrm{SO}$. The results showed that specific capacitance value decreased with exponentially in the increasing of a scan rate. The highest of specific capacitance values of $81.82 \mathrm{~F} \mathrm{~g}-1$ and $10.44 \mathrm{~F} \mathrm{~g}-1$ at a scan rate of $1 \mathrm{mV} / \mathrm{s}$, while at the scan rate of $100 \mathrm{mV} / \mathrm{s}$ found the lowest of $19.67 \mathrm{~F}$ g-1 and $4.66 \mathrm{~F} \mathrm{g-1}$ for HNO3 variation of $25 \%$ and 5\%, respectively. The SEM data showed that the carbon electrode have a hierarchical pore structure and the ED-X result found that highest percentage of carbon element as high as $92.53 \%$ at sample with a variation of $25 \%$ HNO3.
\end{abstract}

Keywords: Supercapacitor, Spesific Capacitance, Scan Rate 


\section{PENDAHULUAN}

Kapasitansi spesifik (Csp) didefenisikan sebagai kemampuan sel superkapasitor menyimpan muatan terhadap rasio massa elektroda karbon yang dinyatakan dengan satuan F g-1 [1]. Kapasitansi spesifik sangat berpengaruh dalam menentukan kinerja superkapasitor. Salah satu cara pengukuran kapasitansi spesifik dapat dilakukan dengan metode siklik voltammetri (CV). Pengukuran dengan metode CV di lakukan dengan jendela potensial dalam range potensial tertentu. Respon pemberian tegangan yang dihasilkan oleh sebuah sel superkapasitor adalah berupa nilai rapat arus, dimana nilai arus ditentukan oleh pergerakan ion-ion didalam sebuah pori elektroda dalam membentuk lapisan pasangan muatan. Kenaikan potensial dalam tiap selang waktu tertentu dikenal dengan istilah laju scan atau laju imbasan. Semakin tinggi laju imbasan akan menyebabkan semakin sedikit kesempatan ion untuk masuk dengan sempurna kedalam pori-pori elektroda, sehingga akan semakin rendah respon arus yang dihasilkan. Akhirnya akan mengurangkan nilai kapasitansi spesifik yang dihasilkan. Kapasitansi spesifik ditulis dengan rumus Csp = I/sxm [2]

Faktor lain yang juga sangat berpengaruh dalam proses peresapan ion kedalam pori adalah bentuk dan ukuran pori elektroda, semakin besar pori akan semakin mudah proses penyerapan ion terjadi. Pada penelitian ini ditunjukkan hubungan pori elektroda dengan laju scan terhadap nilai kapasitansi spesifik yang dihasilkan. Pori elektroda dirancang teratur dalam ukuran makropori dan pada dindingdinding pori mikro diperkaya dengan pori meso dan mikro melalui fase aktivasi fisika dan kimia.

\section{METODE PENELITIAN}

Fabrikasi elektroda karbon dari kayu karet dimulai dengan proses pemotongan, pengeringan, karbonisasi menggunakan gas $\mathrm{N}_{2}$ pada suhu $600{ }^{\circ} \mathrm{C}$, aktivasi fisika dengan gas $\mathrm{CO}_{2}$ pada suhu 850 ${ }^{\circ} \mathrm{C}$, pemolesan dan aktivasi kimia menggunakan $\mathrm{KOH}$ dengan konsentrasi $3 \mathrm{M}$ dan $\mathrm{HNO}_{3}$ dengan variasi konsentrasi 5\%,15\%, 25\%. Sel superkapasitor dibentuk dengan sistem dua elektroda seperti yang telah kami laporkan sebelumnya [3]. Pengukuran sel superkapasitor dilakukan dengan laju scan bervariasi yaitu $1 \mathrm{mV} / \mathrm{s}, 5 \mathrm{mV} / \mathrm{s}, 10 \mathrm{mV} / \mathrm{s}, 30 \mathrm{mV} / \mathrm{s}, 50 \mathrm{mV} / \mathrm{s}$ dan $100 \mathrm{mV} / \mathrm{s}$. Nilai kapasitansi spesifik superkapasitor dihitung dengan menggunakan persamaan berikut [4] :

$$
C_{s p}=\frac{I 0-I d}{s x m}
$$

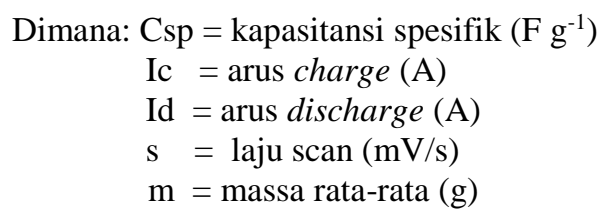

Karakterisasi sifat fisis untuk meninjau struktur morfologi dan unsur penyusun elektroda karbon dilakukan dengan alat mikroskop pemindai elektron dan energi dispersi sinar-X.

\section{HASIL DAN PEMBAHASAN}

Pengukuran sel superkapasitor dengan laju scan yang berbeda telah berhasil dilakukan. Secara umum grafik V vs I memiliki bentuk yang sama pada semua variasi laju scan. Kapasitansi spesifik terbesar didapatkan pada laju scan $1 \mathrm{mV} / \mathrm{s}$ pada setiap variasi $\mathrm{HNO}$.

Gambar 1 menjelaskan hasil karakterisasi menggunakan siklis voltammetri dalam rentang laju scan 1 sampai $100 \mathrm{mV} / \mathrm{s}$. Secara umum hasil yang terbentuk pada Gambar 1(A), 1(B) dan 1(C) menghasilkan bentuk histeresis yang sama.

Gambar 1 (A) memperlihatkan arus yang tinggi pada potensial mendekati 1 V. Hal ini mengindikasikan variasi HNO3 5\% memiliki nilai kapasitansi spesifik yang rendah dan kenyataan ini didukung oleh daerah arus charge dan discharge yang relatif kecil. Gambar 1 (B) menunjukkan 
bahwa grafik yang dihasilkan memiliki bentuk hampir simetris, ini menunjukkan bahwa ion - ion telah mampu berdifusi merata ke pori elektroda karbon. Terlihat dari grafik bahwa kurva Ic-Id variasi HNO3 15\% lebih lebar dari variasi HNO3 5\% yang mengindikasikan bahwa nilai kapasitansi spesifik variasi $\mathrm{HNO} 3$ 15\% lebih besar dari variasi $\mathrm{HNO} 35 \%$.

Gambar 1 (C) menunjukkan rapat arus yang tinggi pada potensial mendekati 1V yang mengindikasikan variasi $\mathrm{HNO}_{3} 25 \%$ memiliki tahanan dalam elektroda menjadi besar. Tahanan dalam yang besar jelas dipengaruhi oleh konsentrasi pengaktivan $\mathrm{HNO}_{3}$ yang semakin besar dan menyebabkan permukaan elektroda dipenuhi oleh banyak pori mikro. Variasi $\mathrm{HNO}_{3} 25 \%$ menghasilkan kurva Ic-Id yang paling lebar diantara variasi lainnya sehingga memiliki nilai kapasitansi spesifik terbesar dibandingkan variasi lainnya. Gambar 1 (D) memperlihatkan grafik perubahan kapasitansi spesifik terhadap variasi laju scan. Terlihat bahwa nilai kapasitansi spesifik mengalami penurunan secara eksponensial seiring dengan penambahan laju scan.

Laju scan rendah menyebabkan ion memiliki cukup waktu untuk berdifusi hingga pori meso dan mikro elektroda karbon. Hal ini menyebabkan kurva arus Ic dan Id besar yang menyebabkan kenaikan nilai kapasitansi spesifik. Sebaliknya pada laju scan tinggi ion hanya sampai pada pori makro, pori - pori mikro yang tidak terisi ion menyebabkan kurva arus Ic dan Id kecil yang menyebabkan penurunan nilai kapasitansi spesifik.
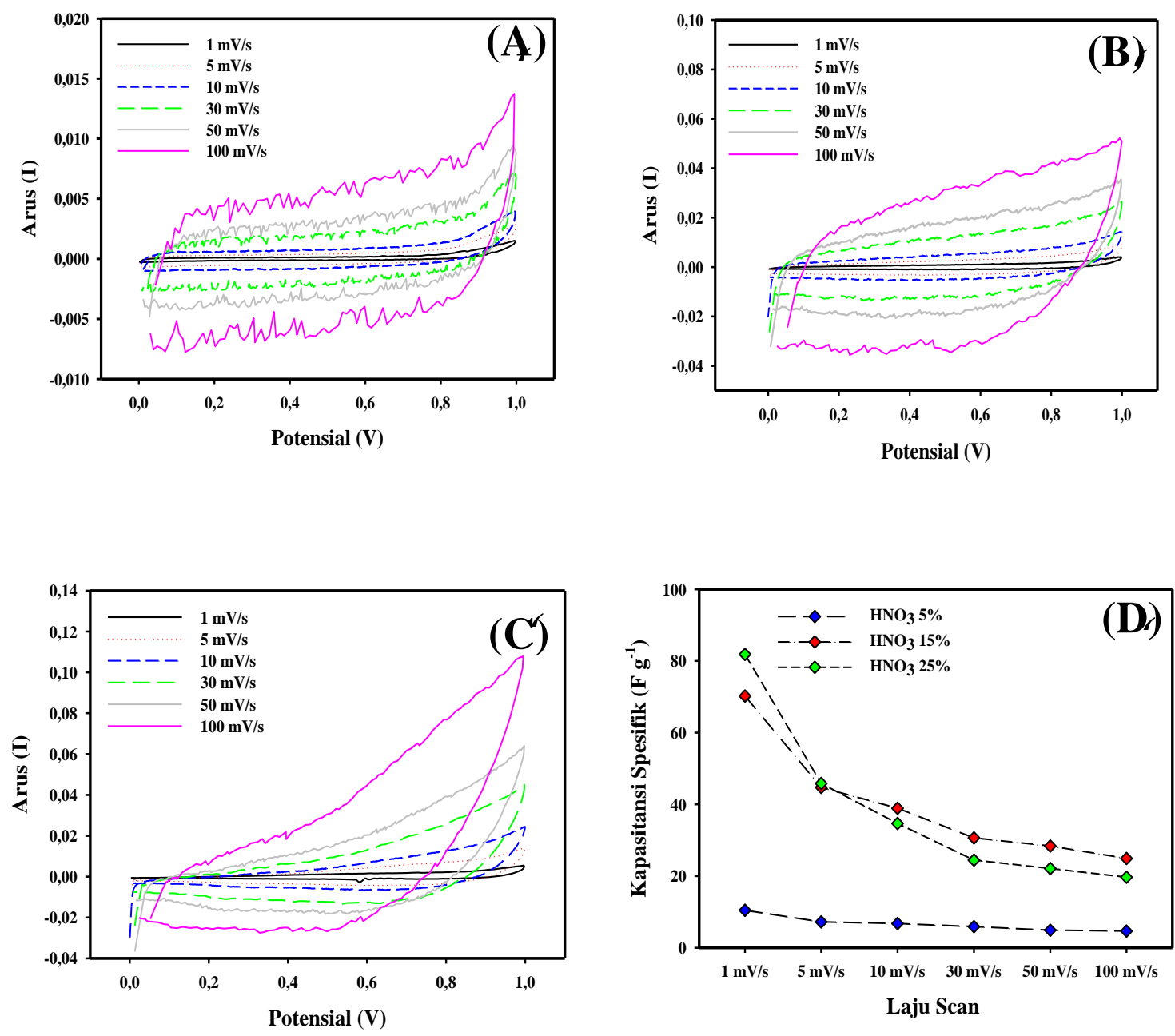

GAMBAR 1. Hasil karakterisasi siklis voltammetri berdasarkan variasi $\mathrm{HNO}_{3}$ (A) $5 \%$ (B) $15 \%$ (C) $25 \%$ (D) variasi laju scanterhadap nilai kapasitansi spesifik. 
Besarnya nilai kapasitansi spesifik berdasarkan variasi laju scan dengan perbedaan konsentrasi $\mathrm{HNO}_{3}$ dapat dilihat pada Tabel 1. Kapasitansi spesifik tertinggi diperoleh sebesar 81,82 $\mathrm{F} \mathrm{g}^{-1}, 70,19 \mathrm{~F}$ $\mathrm{g}^{-1}$ dan $10,44 \mathrm{~F} \mathrm{~g} \mathrm{~g}^{-1}$ untuk laju scan $1 \mathrm{mV} / \mathrm{s}$ pada setiap variasi konsentrasi $\mathrm{HNO}_{3}$ sebesar $25 \%, 15 \%$ dan 5\%.. Sedangkan untuk laju scan $100 \mathrm{mV} / \mathrm{s}$ didapatkan nilai kapasitansi spesifik terendah yaitu sebesar 19,67 $\mathrm{F} \mathrm{g}^{-1}$, 24,91 $\mathrm{F} \mathrm{g}^{-1}$ dan 4,66 $\mathrm{F} \mathrm{g}^{-1}$ untuk masing-masing sampel dengan variasi $\mathrm{HNO}_{3}$ sebesar $25 \%, 15 \%$ dan $5 \%$.

TABEL 1. Data pengukuran kapasitansi spesifik elektroda karbon pada laju scan bervariasi

\begin{tabular}{|c|c|c|c|c|c|c|c|}
\hline \multirow{2}{*}{$\begin{array}{c}\text { Variasi } \mathrm{HNO}_{3} \\
(\%)\end{array}$} & \multirow{2}{*}{$\begin{array}{l}\text { Massa } \\
\text { (gram) }\end{array}$} & \multicolumn{6}{|c|}{ Kapasitansi spesifik berdasarkan variasi laju scan $\left(\mathrm{F} \mathrm{g}^{-1}\right)$} \\
\hline & & $1 \mathrm{mV} / \mathrm{s}$ & $5 \mathrm{mV} / \mathrm{s}$ & $10 \mathrm{mV} / \mathrm{s}$ & $30 \mathrm{mV} / \mathrm{s}$ & $50 \mathrm{mV} / \mathrm{s}$ & $100 \mathrm{mV} / \mathrm{s}$ \\
\hline $5 \%$ & 0,024 & 10,444 & 7,221 & 6,758 & 5,879 & 4,893 & 4,656 \\
\hline $15 \%$ & 0,026 & 70,197 & 44,717 & 38,906 & 30,634 & 28,366 & 24,907 \\
\hline $25 \%$ & 0,029 & 81,823 & 45,828 & 34,673 & 24,469 & 22,109 & 19,675 \\
\hline
\end{tabular}

Gambar 2 menunjukkan hasil karakterisasi morfologi struktur elektroda karbon kayu karet dengan variasi HNO3 5\% dan 25\% dengan perbesaran 500 X. Secara umum gambar SEM memperlihatkan makropori yang seragam pada kedua variasi. Hasil yang sama yaitu bentuk makropori yang seragam juga telah dilaporkan sebelumnya untuk elektroda karbon dari kayu poplar [5]. Gambar 2(A) dan 2(B) memperlihatkan pori-pori makro dari permukaan elektroda karbon. Dari kedua gambar tersebut juga dapat dilihat tampilan pori-pori makro pada Gambar 2(A) banyak yang tertutup oleh kehadiran partikel-partikel kecil, keadaan ini tidak ditemui pada Gambar 2(B).
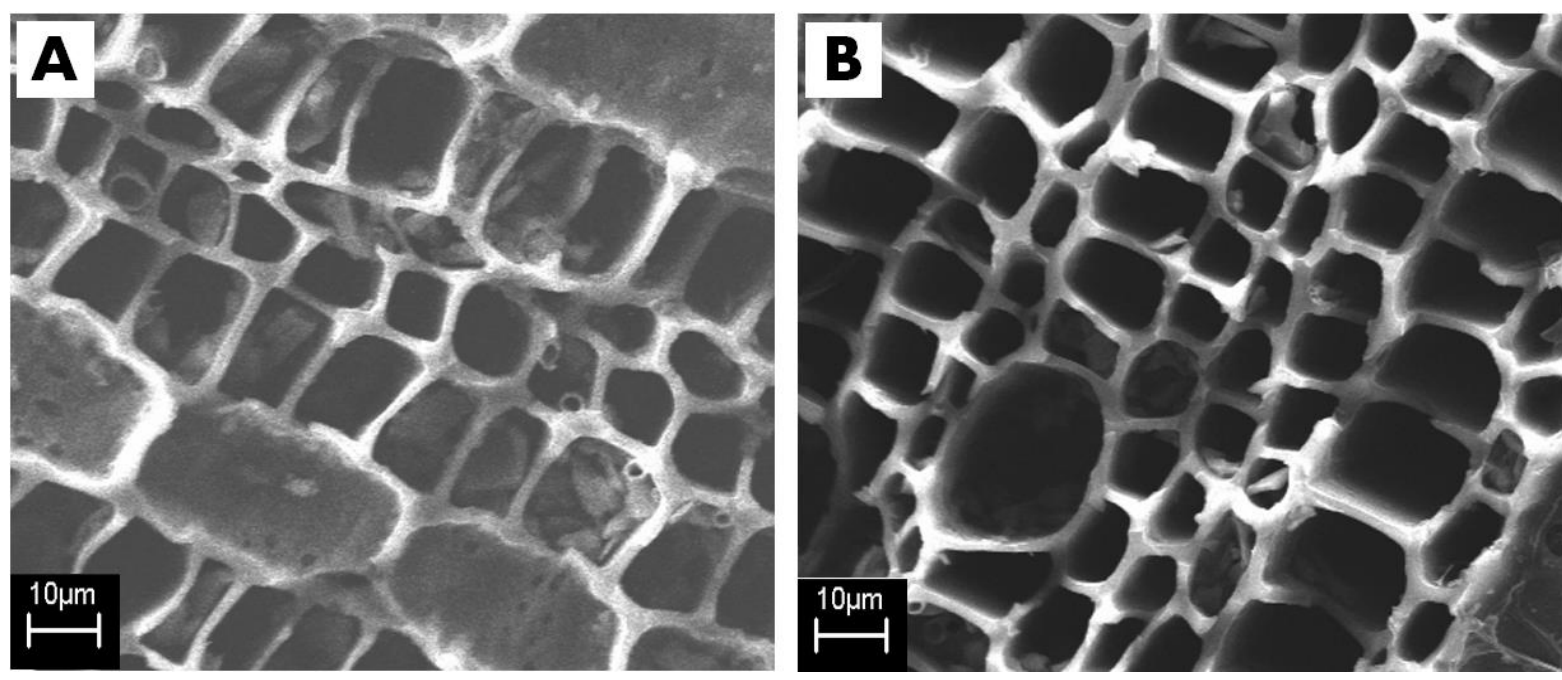

GAMBAR 2. SEM mikrograf pada permukaan elektroda karbon (A) aktivasi 5\% $\mathrm{HNO}_{3}$ dengan perbesaran 500X

(B) aktivasi $25 \% \mathrm{HNO}_{3}$ dengan perbesaran $500 \mathrm{X}$

Gambar 3 menunjukkan hasil pengujian ED-X berupa persentase kandungan unsur dalam elektroda karbon kayu karet. Gambar 3(A) memperlihatkan bahwa untuk aktivasi dengan $\mathrm{HNO}_{3} 5 \%$ memiliki kandungan karbon 89,54\% dengan persentase atomik 92,23\%. Gambar 3(B) memperlihatkan bahwa untuk aktivasi dengan $\mathrm{HNO}_{3}$ 25\% memiliki kandungan karbon 89,74\% dengan persentase atomik $92,53 \%$. Kandungan karbon untuk kedua variasi aktivator hampir sama yaitu sekitar $89 \%$ dengan parameter atomik $92 \%$. 

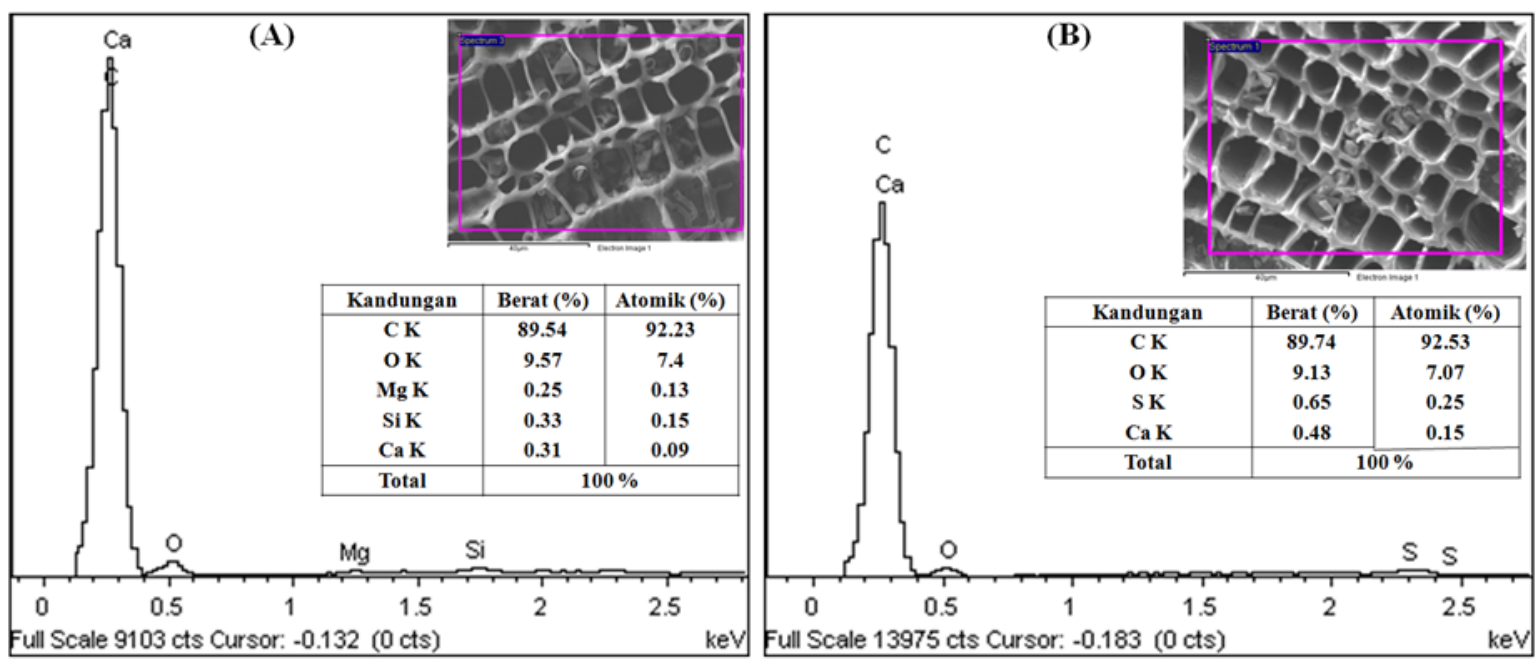

GAMBAR 3. Data kandungan unsur pada elektroda karbon hasil karakterisasi EDX untuk variasi aktivasi (A) 5\% HNO3 dan (B) 25\% HNO3.

\section{SIMPULAN}

Perubahan kapasitansi spesifik terhadap laju scan dengan metode siklis voltammetri telah berhasil dianalisa. Hasil penelitian menunjukkan bahwa nilai kapasitansi spesifik mengalami penurunan secara eksponensial ketika penambahan laju scan. Laju scan rendah $1 \mathrm{mV} / \mathrm{s}$ menghasilkan nilai kapasitansi spesifik tertinggi yaitu sebesar $10,44 \mathrm{~F} \mathrm{~g}^{-1}, 70,19 \mathrm{~F} \mathrm{~g}^{-1}$ dan $81,82 \mathrm{~F} \mathrm{~g} \mathrm{~g}^{-1}$ untuk variasi $\mathrm{HNO}_{3}$ $5 \%, 15 \%$ dan 25\%. Sedangkan laju scan tinggi $100 \mathrm{mV} / \mathrm{s}$ menghasilkan nilai kapasitansi spesifik terendah yaitu sebesar 4,66 $\mathrm{F} \mathrm{g}^{-1}, 24,91 \mathrm{~F} \mathrm{~g} \mathrm{~g}^{-1}$ dan 19,67 $\mathrm{F} \mathrm{g}^{-1}$. Foto morfologi SEM menunjukkan pori-pori makro alamiah yang didalamnya terdapat distribusi pori mikro. Hasil ED-X memperlihatkan kandungan terbesar penyusun kayu karet ini adalah karbon dengan persentase sekitar $92 \%$.

\section{UCAPAN TERIMA KASIH}

Penulis mengucapkan terima kasih banyak kepada Kementrian Riset dan Teknologi atas dana bantuan projek Hibah Kompetensi tahun 2016 dengan judul Nano Karbon Berbasis Limbah Biomassa Sebagai Inti Elektroda Campuran Superkapasitor dengan peneliti utama Dr. Erman Taer, M.Si

\section{DAFTAR ACUAN}

[1] D. Kalpana, S. H. Cho, S. B. Lee, Y.S. Lee, R. Misra, N. G. Renganathan. Recycled waste paper - A new source of raw material for electric double-layer capacitors. Journal Power Sources. 2009.190: 587.

[2] E. Taer, M. Deraman, I.A. Talib, A. A. Umar, M. Oyama, R. M. Yunus. Physical, electrochemical and supercapacitive properties of activated carbon pellets from precarbonized rubber wood sawdust by CO2 activation. Current Applied Physics 10 (2010) pp. 1071-1075.

[3] E. Taer, M. Deraman, I. A. Talib, A. Awitdrus, S. A. Hashmi, A. A Umar.Preparation of a Highly Porous Binderless Activated Carbon Monolith from Rubber Wood Sawdust by a Multi-Step Activation Process for Application in Supercapacitors. International Journal of Electrochemical Science. 6. pp. 2011. 3301-3315. 
[4] R. Farma, M. Deraman, I.A. Talib, Awitdrus, R. Omar, M.M. Ishak, E. Taer, N.H. Basri and B.N.M. Dolah.Effect of Electrolyte Concentration on Performance of Supercapacitor Carbon Electrode from Fibers of Oil Pal Empty Fruit Bunches. AIP Conference Proceeding. 2015.

[5] Liu, M.C. Kong, L.B. Zhang,P. Luo, Y.C. Kang,L. Porous wood carbon monolith for high performance supercapacitors. Electrochimica Acta.60. pp. 2012.443- 448. 